Espen D. H. Olsen

\title{
4 Welfare State Discourse and Citizenship Politics: From 'Silent' Policy to Steering Logic
}

Citizenship is the primary organizing principle for individuals in political life. Through norms of membership, exclusive rights, notions of participation and a sense and idea of belonging, (most) citizens of the world have citizenship status in a territorial state. Through this citizenship, citizens are members of a given political community. Moreover, the political community is also closely wedded to full membership of the polity through social and economic rights. This description of citizenship is by no means controversial or radical. Yet, it has been challenged politically and scholarly over recent decades. Europeanization, globalization and the rise of international law have blurred the boundaries between states. Moreover, the modern triptych of nation, state and citizenship is no longer a given. EU citizens (and EEA citizens) have extensive transnational rights in other countries than that of their own citizenship, and we see increasing proliferation of human rights that are not contingent on membership in the political community of the state where a non-citizen resides. In addition, there has been an increased interest in issues linked to citizenship in public debates. Issues related to multiculturalism, nationalism, identity and the integration of immigrants into society are routinely debated in most European countries. And not only that, the organization of state institutions themselves through for instance New Public Management reforms continues to raise questions about rights provision, citizens' duties and the boundaries between individuals and collective institutions. This is not least the case in the Nordic countries, where the welfare state and the Nordic model are connected to a specific organization of the private/public interface of modern political order.

This chapter addresses the link between citizenship reform and contemporary discourses on the organization of the welfare state, taking Norway as an example. Until the post-Cold War period the meaning and significance of citizenship was seldom debated in Norway. If we compare with the importance of citizenship in American politics or 'Staatsbürgerschaft' in the German reconfiguration of 'postnational' identity after World War II, citizenship has historically been a virtually silent topic in Norway. This shifted, arguably, in the decades after 1989. Why is this so? The argument put forward is that citizenship gradually has become a strong institutional signifier and instrument for the management and gatekeeping of full membership in Norwegian society. Crucial to the argument is the tie between citizenship as a political concept and welfare rights. Some may argue that this is at the outset weak. Citizenship signifies no more than full membership extended to full political rights. Many non-citizens have extensive social rights through legal residence, a kind of 'semi-citizenship' (see Cohen, 2009). Yet, I argue that citizenship is also political in the sense that it enters into discourses on inclusion and exclusion in society (see also Schierup, Hansen, \& Castles, 2006). The status of citizenship is but one of several 
personal statuses an individual can inhabit in a rights-based community, yet many non-citizenship statuses can ultimately lead to full citizenship through naturalization (Janoski, 2010). The final threshold arguably says something about inclusion and exclusion in the political community. Moreover, recent research on citizenship policies in Europe has highlighted some trends towards more restrictive rules and practices on acquisition and naturalization, despite the proliferation of postnational ideas and international norms in recent decades (Howard, 2009). In other words, there is increasing evidence that citizenship is making a 'return' as a political instrument for controlling membership in internationalized societies.

Citizenship overall has developed from silent policy to a stronger steering logic related to the universal welfare state model that is at the core of the Nordic model. This change over time is linked to three interrelated macro-political and social developments that have become dominant in Europe over the last three decades: globalization, Europeanization and migration. Globalization has led to increased interdependence between states and economies. This interconnected nature of world politics means that state institutions and national political cultures are no longer insulated from outside influence. Migration is a crucial part of this development. As the world has become 'smaller' in terms of communication, migration has become a more prevalent option for persons who seek a better life financially or who are in need of protection from terror, war or persecution. At the same time, the more prosperous parts of the world have welcomed the additional labour force that stems from migration. This process of migration is also part of the process of Europeanization through rights of free movement for EU and EEA citizens.

Citizenship is often discussed as a universal term that holds the same meaning across time and political space. However, I start from the supposition that citizenship is highly contextual. Its different instantiations in national settings and links to supranational and societal developments are a matter of praxis, not normative theorizing. Yet, there is a core generic meaning attached to citizenship; it is composed of rules of membership, basic rights and a notion of belonging to the political community (see Olsen, 2008). In other words, any analysis of citizenship needs to take this into account and study the ways in which citizenship is conceptualized and institutionalized both as an individual status and as a set of norms and practices that govern the nexus between individuals and the state.

The theme of this volume is, broadly speaking, 'institutional change in democracy'. This chapter contributes by highlighting what Walzer (1983) has called the 'distributive effects' of membership regulation in modern politics. It highlights the discursive links between ideas and policies on distributive outcomes (welfare state provisions for all full members as well as political inclusion), normative regulations (citizenship policy) and specific institutional functions (inclusion and exclusion in the political community).

In studying this development, the chapter utilizes the concept of discursive institutionalism (Schmidt, 2010). In so doing, the chapter analyzes the discursive 
interaction between citizenship discourse and welfare state discourse by focusing on the substantive content of ideas related to citizenship policy. Empirically, the chapter therefore focuses on two data streams. The first entails ideas of citizenship embedded in concrete citizenship and naturalization policies. The second is the idea of citizenship that emerges from public committees engaged with the preparation of policy reform and the framing of national citizenship in the new global and European settings. Empirically, the onus is put on linkages made between access to full membership in the welfare state and ideas about citizenship in welfare state discourse. In short: in what ways have new ideas and policies on citizenship become framed as part of welfare state debates in Norway as one of the most advanced welfare societies in the world?

In the next section, a brief sketch on the academic debate on citizenship post1989 is presented. Following this, I present the research design of the chapter with special emphasis on how to study the discursive linkages between 'welfare state' and 'citizenship'. The rationale behind studying Norway as an example of the Nordic model is briefly discussed before the chapter ventures into the empirics and main findings. As a conclusion, I discuss some conjectures on the democratic implications of the findings.

\subsection{Background: The Debate on Citizenship Post-1989}

Citizenship was for a long time a silent subject in political science and political sociology. In the wake of the behavioural revolution and the advent of institutional theories, citizenship was for the most part the purview of political theorists and their normative theories of social justice, welfare distribution or political equality. The most notable exception was T.H. Marshall's (1992 [1950]) seminal work on the development of citizenship rights in Britain in the $19^{\text {th }}$ and early $20^{\text {th }}$ centuries. With the fall of the Berlin Wall and the end of large-scale communist rule in 1989 and the ensuing years, however, citizenship made a new appearance in the work of political analysis.

There are several reasons for this renewed interest in issues of citizenship, yet arguably some stand out. The end of communism ushered in a sense that politics again mattered, not only such as in 'high politics' but also for the ways in which we organize ourselves as political communities composed of groups as well as individual citizens (Kymlicka \& Norman, 1994). Identity, culture and (national) selfdetermination made a 'comeback' in European politics. But not only that, these processes were clearly supplemented, and some would argue countered, by the increased internationalization of European politics and societies. The EU went into full-on union mode, even planning a common currency, common security policies and indeed a common concept of EU citizenship. Human rights discourses, the opening of markets and new technologies spurred the process of globalization with the noted understanding of political elites that the world was ever more 'interconnected' (Held 
et al., 1999). This interconnectedness was further visible in new waves of migration within Europe as a result of free movement as well as extra-European migration as a consequence of conflicts and poverty in other regions of the world.

These three parallel and intertwined developments have been seen both as opportunities and possible threats to European democracies. Central to the argument here is that they were part and parcel of the new academic and political interest in citizenship post-1989. They raised awareness of the increase in 'porous' borders between territorial states and subsequently the boundaries of nations as what Anderson (1987) called 'imagined communities'. This gave rise to several new normative, theoretical and empirical debates on the distinctiveness of European integration, the proliferation of (human) rights in international integration and multicultural politics. More concretely, the interest in what we can call the transformation processes of the territorial nation-state had a strong purchase on academic debates on citizenship, with specific emphasis on rights, membership and identity.

Foremost, the scholarly debate centred on how processes 'beyond the nationstate' would lead to a reconfiguration of citizenship. One argument was that processes such as Europeanization and globalization could lead to a severing of the strong ties between access to rights and citizenship (Gerstenberg, 2001; Habermas, 1998). Rights would become more important than the status of membership itself. EU citizenship was held to be the first step in the development towards postnational citizenship, where citizenship finally got rid of the 'shackles' of nationalism. Empirically, one example held out in this debate was the fact that the practice of dual citizenship is increasingly accepted by states that previously stood firmly on the idea of unitary citizenship (Kivisto \& Faist, 2007; Spiro, 1997). Moreover, the phenomenon of transnationalism is no longer novel but instead a fact of globalized politics and societies. Transnational flows of migrants, services, goods and capital increases 'the right to have rights' for individuals in their countries of residence in addition to that of their nationality (Soysal, 1994). The European integration project is in itself constructed on the foundation of free movement (Maas, 2007). Member states have duties not only towards their own nationals but also towards European citizens.

Moreover, the issue of identity took centre stage. In the European and globalized context, identity was increasingly debated as flexible and potentially liberating. The debate on multicultural citizenship is a case in point (see Kymlicka, 1995). Identitybased claims for group rights and the recognition of minorities gained much support in theories of citizenship from the 1990s onwards. At the same time, so-called communitarians argued that this development veered from the idea that to be a full member of a vibrant 'community of strangers', some minimum of common culture, language and national identity was needed (see Miller, 1995).

Following from these academic debates one would expect a gradual transformation of citizenship where membership is less important for status, giving way to individual rights and multiple identities in the vein of what Thaa (2001) has coined 'lean citizenship'. Yet, I argue that this has not come to fruition. Citizenship 
has in many European countries become more restrictive and more tightly linked to high thresholds in regard to access to membership. Norway has partly followed the same path. Why is this so? This chapter discusses this shift as a reaction to external pressures that have had a special purchase on conceptions of the welfare state and its sustainability in the future.

\subsection{Studying Citizenship Politics and Welfare State Discourse}

Citizenship is one of those concepts that we all have a connection to as everyday citizens. We are all (except for the very few stateless persons) citizens of some state entity. It is therefore not surprising that citizenship for some is taken for granted. It is just there, existing as a background to whatever life-projects we may have as individuals or members of different societal groups. Yet, this layman's understanding of citizenship overlooks the centrality of the concept and institution of citizenship to our existence in modern political communities. Citizenship is increasingly utilized discursively as an instrument for controlling access to full membership and thereby also access to the whole range of rights, including welfare rights in the world's most advanced 'social states', those of the Nordic model. In other words, against those that would hold that social rights are more strongly linked to residence than citizenship as such, I argue that it still matters a great deal who are granted membership of these polities and who are not. As Faist (2009, p. 16) has highlighted, '[n]ationality thus serves as the mechanism that upholds social exclusivity', both within a state and between states. Citizenship is in the final instance the only path to full inclusion, also in the Nordic welfare states.

Writing about citizenship in The Politics, Aristotle (1992, p. 168) claimed that '(...) there is no unanimity, no agreement as to what constitutes a citizen'. Since classical times this contested character of citizenship has been subject to a plethora of different realizations in practice as well as understandings in theory (Bellamy, 2004). In studying the interplay between welfare state discourse and citizenship politics, ${ }^{1} \mathrm{I}$ define citizenship on the most general level as a status of individuals tied to a territorial state. ${ }^{2}$ This means that citizenship is imbued with the existence of political or legal orders which, formally or informally, establish a relationship to individuals through a monopoly of force (see Weber, 1978, pp. 54-55) and/or (legally binding) rules which

1 When I refer to citizenship policy, this relates to concrete policies and laws on citizenship. The notion of citizenship politics is broader in meaning, taking in the role that citizenship also plays in other policy areas and as an idea for societal development and political organization.

2 Of course this would preclude EU citizenship as 'citizenship' in a definitional sense. EU citizenship may also have strong traits of citizenship in the statist reading, yet it is not citizenship of a state. Nevertheless, EU citizenship and notions of rights 'beyond the nation-state' has an impact on discourses of national citizenship (Vink, 2005). 
serve to structure the scope of individual action (see Olsen, 2007, p. 118) through norms of membership, individual rights and/or duties. This signifies that citizenship links individuals to a collective order. Thus, citizenship would hold no meaning if it was devoid of a collective component (see Arendt, 1968, p. 81ff; Walzer, 1983, p. 34). On the general level, this collective component is obvious in that citizenship as a status is always bestowed by someone to the individual in question.

Notwithstanding its contested character, citizenship gives rise to certain salient questions, issues and problems. I argue that these are linked to the intrinsically individual and collective characteristics of citizenship. Michael Walzer (1983) writes on membership as the main organizing principle for how political communities organize themselves as communities of individuals. Membership is therefore marked by the inclusion/exclusion nexus of political community. If all individuals were part of the same community, the notion of membership would not be of importance for political thought. As the world is divided into different political entities - that is, states - membership becomes crucial for both the individual and the state. Membership is in this sense the 'first mover' of citizenship politics. Theoretically, rights only follow after the membership decision. In practice, there is a continuum of personal statuses of rights and attachment to a state, from the stateless person to the citizen. Temporary or permanent residence is a form of membership that renders certain rights to individuals. For instance, several social rights are based on residence. Moreover, in the European context, EU citizenship is part of a transnational scheme of cooperation where the citizens of member states are accorded equal rights and can redeem the right to non-discrimination when they move to another member state. Is citizenship, then, enveloped in a process of redundancy in today's Europe? I argue that it is not. Only through admission as member of the polity does an individual enjoy the whole range of citizenship rights, including all social, political and civil rights. What specifically characterizes membership for Walzer is the fact that those already included in the community 'do the choosing'; that is, they set the rules for admission to the political community. In this sense, citizenship is also strongly imbued by a sense of identity - the understanding of 'we' as citizens and 'they' as non-citizens - that is, the stipulation of 'who we are' and 'what distinguishes us from others' in terms of both individuals as part of a collective community and the community as such. Identity can thus be understood as a reflection on what a given political community entails and what sets its citizens apart from other citizens, not only through membership decisions but also in terms of how the very community is conceived as such.

The membership decision has widespread distributive consequences both in terms of membership itself and the goods that follow from being a member in state A and not state B. While some goods may also be open to non-citizens, the collective of citizens can through their representatives in the democratic process at any time narrow such access as long as it is not in breach of obligations under international law. Indeed, work in historical sociology has highlighted how the social question in 
modern Europe was linked to the fulfilment of social rights for all citizens, thereby inclusive citizenship (Flora, 1987). Citizenship is therefore highly significant as political rights are necessary in democracies to create and sustain social rights (Faist, 1999, p. 13). In this way, social rights in the welfare state are transformed from mere 'entitlements' of a legal kind to the ability of citizens to make use of such liberties to influence their opportunity structures and life chances (see Sen, 1999). In this chapter, the onus is on the membership dimension of citizenship as the institutional expression of the normative regulation on inclusion or exclusion from the (welfare) state. The other dimensions follow from membership (rights and participation) or are in some discourses held to be a prerequisite for membership (identity). As the aim of this chapter is to highlight discursive linkages between welfare state discourse and citizenship politics, empirically the focus will be on ideas of membership in citizenship. $^{3}$

The chapter analyzes the substantive content of ideas related to citizenship policy as well as the discursive interaction between citizenship politics and welfare state discourse. The analytical idea of discursive institutionalism stems from the notion that ideas matter in politics. This may seem to be common sense, yet in modern political science 'interests' or 'norms' were for a long time the main game in town. Schmidt (2010) argues that ideas should be studied in terms of their substantive content in policy-making processes and as part of interactive processes of discourse in a given institutional context.

This analytical programme is especially suited for the aims of this chapter as it gives a contextual and relational definition of discourse as 'the exchange of ideas' (Schmidt, 2010, p. 15). What follows from this is, then, a more dynamic understanding of 'institutions' than the one normally found in institutional theory. Institutions are at the core defined as 'structures and constructs of meaning' (Schmidt, 2010, p. 1). More concretely, Schmidt highlights how there is agency in institutions through the background ideational abilities of actors that play roles in maintaining institutions and the foreground ideational abilities of actors in changing them.

In this chapter, I study the interlinkages between the boundaries of the welfare state and the concept and institution of citizenship. Both are 'institutions', albeit in a somewhat different manner. Citizenship is a personal status given to individuals but also has institutional properties in that the definition of access to citizenship through membership, rights and belonging has a structuring effect on the makeup of the political community. The concept of the welfare state covers both a distinct

3 Much theorizing and empirical research on citizenship focuses on 'conceptions' or perceptions of citizenship as a set of different practices of membership, rights, participation and identity. This chapter does not aim to study conceptions of citizenship as such but rather the interplay of 'ideas' of citizenship and welfare state discourse. In this sense, it is the ideas on membership and access that matters rather than some 'full' conception of citizenship. 
way of organizing the modern state and the myriad of societal, political, democratic, legal and economic institutions that make up this system as well as structure the links between citizens and welfare policies and programmes. The chapter therefore confines its analysis of the welfare state/citizenship nexus to a study of the discursive linkages between ideas and notions of membership in citizenship politics and welfare state discourse. This is not premised on theorizing a causal link between independent and dependent variables. It is rather to make sense of and analyze the different ways in which the importance of citizenship for the structure of the welfare state has consequences for conceptions of and policy changes to citizenship institutions and membership norms. In this sense, the chapter is interpretative in methodological terms. In being interpretative, it still makes a claim to highlight significant changes to citizenship in welfare state discourse. These changes are traced discursively in the data. This means concretely that the analysis seeks to address shifts in emphasis regarding the place of citizenship and basic dimensions such as membership and rights in welfare state discourse in official documents.

In terms of data sources, the chapter first sets a baseline view of the state of citizenship around 1990 when the chips were dealt anew in terms of the international relations of European states, including Norway. Following this, the analysis focuses on official reports and policy chapters related to welfare state policy and citizenship politics. In so doing, the analysis traces interactions between notions regarding the welfare state and ideas of citizenship as membership, with special emphasis on issues related to access to welfare rights.

\subsection{Citizenship in Norway: From Silent Policy to Steering Logic}

Until the 1990s there was hardly any serious political debate on citizenship in Norway. ${ }^{4}$ The citizenship law originated from $1950^{5}$ and did not go through any significant policy changes for half a century. There may be many reasons for this, but it seems obvious that Norway's status as a relatively homogeneous country developed after World War II on the idea of a strong state and extensive welfare provisions excluded debate on citizenship itself. Membership was more about social rights and participation in the labour market than political citizenship.

The main idea in the 1950 law was that of unitary citizenship; dual citizenship was prohibited. Nevertheless, in practical terms it was tolerated administratively (NOU 2000:32, Ch. 4). This idea of unitary citizenship is still important when considering the status of citizenship in Norway in the postwar years. Discursively, the notion of 'one state, one citizenship' fell straight into the common ideas of citizenship in the 'era

4 In the following, all quotes from Norwegian are translated by the author. 5 Lov 8. desember 1950 nr. 3 om norsk riksborgarrett. 
of the nation-state'. Both politically and academically, citizenship was understood as membership in a nation, submerged under a clearly defined territorial state. Clearly, the 'substance' of this citizenship was different between states (Howard, 2009). Some countries had stronger demands on settling an identity as part of citizenship due to multiculturalism or multilingualism, such as Canada or the United States, while others forged citizenship in what was understood as a 'homogeneous' population. In Norway, the citizenship law was in fact devoid of identity-oriented measures or requirements. No specific ideas of a pre-given identity or language skills were present. This was also the case with neighbouring Sweden, while Denmark has had a strong tradition of such communitarian ideas as part of the rules on acquisition and naturalization (see Olsen, 2005).

Citizenship has been scarcely debated in the Norwegian public sphere. The welfare state has been a more pronounced part of public discussions, yet the debates were until the 1990s mainly on the level of provisions, grounds for universal rights, material entitlements and how to improve the position of minorities or women (see Hernes, 1988). This was seen, then, through the prism of participation in society more so than citizenship as cultural membership. What is striking about the debate from the 1990s onwards is the clear shift in the volume as well as the content of debates on membership, rights, welfare provisions and the boundaries of the welfare state. Arguably, citizenship became more pronounced as part of debates on political community beyond the inclusion of minorities or political participation. This amounts, I argue, to a considerable discursive change in Norwegian society, which, to put it crudely, marks a shift from universalism as the inclusion of ever more groups and minorities as full members of society to particularism as a notion of the collective beyond rights. In this sense, it can be seen as a gradual shift from a community of rights (see Dobson, 2007) to something more akin to communitarian notions of belonging (see Taylor, 1985). What is more, this shift cannot be linked to only one political ideology. It has persisted since the beginning of the 1990s through different majorities in the Norwegian Parliament as well as with governments from both the left and the right of the party political spectrum. It is rather a major discursive shift that also has institutional effects for political decision-makers, bureaucracies, parties and (non-)citizens. In this chapter, those effects are not accounted for through causal explanation but rather through highlighting discursive linkages and developments where welfare state policy and citizenship have become more closely interconnected.

Public discourse on issues related to immigration started to turn in the 1980s. The Progress Party (FrP) gained more support, partly due to its staunch stance on immigration and proposals on tougher requirements for the integration of migrants already residing in Norway. Slowly, other parties, such as the Labour Party (Ap) or the Conservatives (Høyre), started to discuss such issues as well, albeit with less of a critical stance on immigrants as a group in Norwegian society. Yet, there were no major policy shifts or institutional changes in this period. Government coalitions 
were relatively stable, and the most contentious political issue in Norwegian politics towards the late 1980s would become the question of EU membership.

Against this background, debate on citizenship and the need to reform the Norwegian Citizenship Law, which had not been reformed since 1950, still took place gradually in the 1990s. In 1999, a Norwegian Public Commission ${ }^{6}$ was given the mandate to review Norwegian citizenship policy both in terms of judicial practice at the time and with an added mandate to propose possible changes and modernizations to the law. Several reasons were cited by the centre-right government for setting up a commission on citizenship at that point in time. The long-standing inertia in policy terms was one, interestingly for the argument of this chapter, the government also linked directly to issues of migration and integration in Norwegian society. In the words of the Royal Resolution that formed the Public Commission: 'The Commission is also asked to assess further questions, among them how the acquisition of Norwegian citizenship can contribute to integration and civic participation' (NOU 2000:32, p. 3). This is interesting as the Norwegian citizenship debate until the forming of this public commission had been virtually silent as a whole, but especially so on the political, societal and indeed individual consequences of different citizenship practices. In Norway, the legal practice and bureaucratic consequences of different rules (and possible changes to them) had been at the forefront of public discussion on citizenship. As a result of this mandate from the government, this time around there was clearly an awareness of the broader significance of citizenship not just as policy (as rules and regulations) but also as politics (as indicative of broader societal issues). This volume analyzes institutional change from different angles and in different societal sectors. In the field of citizenship, the linkage between notions of policy and views on politics is of central importance. As highlighted previously, Walzer (1983) made the argument that specific understandings of identity in the political community will have an impact on its membership politics - that is, its values, rules and regulations attached to citizenship. In other words, how policy solutions are framed in political debate and the 'rules of the institutions' (here: citizenship) are clearly interlinked.

In the comparative citizenship literature, it has been shown how the discourse on citizenship changed in this direction in Europe from the 1990s onwards (Howard, 2009; Kivisto \& Faist, 2007). In this 'citizenship turn', both scholars and decisionmakers started to address the issue of whether multiculturalism could serve as a new mode of inclusion, especially through renewed ideas of citizenship as more fluid and open than the 'traditional' nation-state model that had dominated in the first decades of the postwar era (see Kivisto \& Faist, 2007, p. 7). In other words, the Citizenship Commission was set up in the midst of a clear discursive shift of citizenship politics in

6 On the phenomenon of Norwegian Public Commissions and their role as policy advisory bodies in the Norwegian political system, see Tellmann (2016) and Krick and Holst (this volume). 
Europe, one where the subject of inclusion and membership would become the focal point for the next two decades.

What did this turn into in terms of concrete policy recommendations and not least possible discursive linkages to welfare state policies and social provisions? The Citizenship Commission brought on a wide discussion of the whole citizenship field. One prominent theme was to clarify certain rules for the acquisition of citizenship at birth and through naturalization as bureaucratic practices had drifted somewhat from the law itself. The most contentious issue of dual citizenship policy. Moreover, as I will show, the arguments and grounds put forward linked up with welfare discourse as well as the migration/identity nexus of debates on political community.

Inclusion and membership through citizenship is a forceful institutional instrument for integrating newcomers into a political community and a territorially organized society. That membership in a polity is always decided by those who are already members (Walzer, 1983) implies that citizenship for an immigrant or refugee tells them that 'we' as a community welcome them as members of 'our' community. This membership, then, gives full access to rights and entitlements. The Citizenship Commission delved into this issue by tackling the question of dual or multiple citizenship first-hand. Dual citizenship had been prohibited in the 1950 law on citizenship. The Citizenship Commission argued for accepting dual citizenship and making this a part of Norwegian Citizenship Law: 'One must always acknowledge that immigrants will remain connected to their homeland. Such bonds are not rescinded upon naturalization to Norwegian citizenship and by withdrawing the original citizenship. Norwegian citizenship will be sought to access rights here or because the applicant wishes to confirm or further their integration into Norwegian society' (NOU 2000:32, p. 121). The argument was strongly linked to the notion of multiple identities and the need to secure full membership for legal residents who seek naturalization (ibid., Ch. 4). There was, however, a minority view from one member of the Commission who argued against dual citizenship. This member argued that dual citizenship would be in breach of the principle of equality upon which citizenship is premised in democratic political communities (ibid., p. 127). Moreover, this view put forth the idea that the bond between citizens in the political community is based on trust relations that dual citizenship breaches: 'Norwegian society has more than most societies been marked by trust, a sense of community and solidarity between the citizens... and this is anchored in - has its basis from - the principle of equality as it has been confirmed and renewed through targeted public policies for the common good' (NOU 2000:32, p. 124). The minority position did not make explicit reference to the boundaries of the welfare state in the part on dual citizenship. Yet, in laying out different notions of citizenship, the same member wrote a separate remark where the idea of unitary citizenship in the well-defined political community of a nation-state was explicitly linked to the development of the welfare state (ibid., pp. 70-81). For instance, it was highlighted that '(...) the building of the welfare state in the $20^{\text {th }}$ century has without doubt been part of community building in Norway, both 
politically and culturally' (ibid., p. 80). We cannot extrapolate from the Citizenship Commission the strong discursive shift of the linkage between controlling access to welfare provisions and notions of membership that constitute the hypothesis of this chapter.

The majority position to legalize dual citizenship in Norway, however, did not gain traction politically. The communitarian reasoning of the minority view won through. The Norwegian Parliament subsequently passed a new Citizenship Law where the principle of unitary citizenship was retained. ${ }^{7}$ In the parliamentary debate, the link between citizenship, welfare rights and membership was in fact made. The Rapporteur ${ }^{8}$ on the citizenship law, Anita Apelthun Sæle from The Christian Democrats $(\mathrm{KrF})$, explicitly stated: 'Norwegian citizenship rights are far-reaching. The welfare society provides a safety-net and social rights. One clearly has the right to live in one of the world's best countries... Then it is reasonable to demand something from a person that seeks to take part in this common good'. ${ }^{9}$ The communitarian minority position from the Citizenship Commission in fact became policy. The statement of the Rapporteur also clearly points in the direction of a shift towards reasoning in terms of a high threshold for access to membership because Norway has a welfare state with generous welfare provisions. This policy decision from the Norwegian Parliament also held a significant majority against the votes of one minor opposition party, the Socialist Left (SV). There was, in other words, a clear political consensus that Norwegian citizenship should remain unitary in the age of Europeanization and globalization as a 'bulwark' for the boundaries of the welfare state. In this sense, we can infer the frame of using citizenship policy as an institutional instrument of steering related to the welfare state.

Why is this relevant for the argument of the chapter? Although there was not much direct linking between the membership dimension of citizenship and access to welfare state provisions, it can be argued that the debates concerning the work of the Citizenship Commission spurred more citizenship politics in Norway. This new concern for inclusion and exclusion in the political community would clearly become a salient issue of public discourse in Norway in the 2000s. It can be argued that this concern contributed to new exchanges of ideas where citizenship was no longer framed as only a legal institution but also political and social in terms of contributing to the processes that shape society.

The issue of migration became an important topic of political debate in Norway at the beginning of the 2000s. It can be argued that Norway by this time had finally become a state and society marked by migration (see Kjelstadli, Tjelmeland, \& Brochmann, 2003). In addition, the Eastern enlargement of the EU posed new issues

7 Lov om norsk statsborgerskap, Besl. O. nr. 88, 31 May 2005.

8 In Norwegian: 'Saksordfører'.

9 Stortinget, 2004-2005, meeting, 31 May 2005. 
of labour market politics and social rights as new EU citizens could travel to and work in Norway as a consequence of the free movement of persons. In this new policy environment, the debate on what can be called the 'sustainability' of the Norwegian welfare state gained considerable political and academic traction. It was in this context that the centre-left coalition government formed the Welfare and Migration Commission (commonly referred to as the Brochmann Commission after its leader) in May 2009. The premise and background of the commission was that the link between increased flows of migration (both intra- and extra-European) needed to be addressed in its intersection with the welfare state of Norway as one of the countries in the world with the highest standard of living (NOU 2001:7, p. 32). This development is of clear interest to the argument of this chapter. Norway went from virtual silence on citizenship topics up until 1990 through a phase of debate on multiple citizenship and multiculturalism at the beginning of the 2000s to an explicit discursive shift of direct linkage between different personal statuses and welfare politics around 2010.

A caveat is in order here. The Welfare and Migration Commission did not address citizenship explicitly. Its focus was on different personal statuses and social groups linked to the migration/welfare nexus. In this sense, a counter-argument to the reasoning of this chapter could be that the discursive linkages between welfare discourse and citizenship are not present to the extent that I argue. Yet, there is an argument here that hinges on how we conceptualize citizenship politics. Citizenship can be addressed purely as a legal institution signified by the clear distinction between the citizen and the non-citizen. This, however, is too crude for the analysis of the institutional meaning of citizenship in a political, social, cultural and economic sense. The concept of membership is central to this. Citizenship is the 'ultimate' membership status, giving a person the full range of rights. Memberships can, however, also take the form of different statuses of 'semi-citizenship' (Cohen, 2009). Yet, discourses on membership and access to rights are always in some way related to the politics of citizenship as different semi-citizenships can be routes to full citizenship down the road, for instance, for long-term resident migrants. In this sense, policy appraisals and policy recommendations at the intersection between welfare and migration will be imbued with notions of membership and specifically how these intersect with access to rights and the boundaries of the welfare state. Consequently, I will show in this section how the Welfare and Migration Commission on several counts addresses notions of membership also related to citizenship in the legal sense.

The main idea of the Welfare and Migration Commission was that mobility, migration and the sustainability or future of the welfare state are intimately linked. In addressing the question of the sustainability of the welfare state, the commission therefore applied a 'broad' operationalization of its mandate to include both positive and negative consequences of migration for the welfare state (NOU 2011:7, p. 9). Moreover, the commission expunged the theory that the consequences would be linked to '(...) who arrives, what resources they bring and their degree of integration in working life and society' (ibid., p. 9). This linking of migration and welfare also 
connects to the notion of membership. Policies and measures should be in place so as to 'lead' new 'members' of society towards realizing their opportunity by taking up an occupation in line with the majority population. In other words, the commission clearly distinguishes between citizens as insiders and non-citizens as outsiders, at least in the sense of full membership vs. partial membership. I interpret this idea as a manifestation of something akin to a Walzerian notion of full membership as contingent on inclusion into the habits, values and norms of the majority population - that is, those who do the 'choosing', as was highlighted earlier in the chapter.

Further, the commission highlighted that the Norwegian welfare state was formed at a time when mobility across borders was less prevalent. Moreover, it stated that the welfare state '(...) in many ways has represented a societal integration project with three main ingredients: democracy, citizenship and modernization' (ibid., p. 11). Citizenship is still the main access point to the full set of political, social and economic rights in the Norwegian model. Arguably, then, the commission makes the concession that welfare and citizenship are intimately linked. In other words, the image of citizenship policy as taking an institutional gatekeeper role starts to become visible in the welfare state discourse that the Welfare and Migration Commission worked under and became a part of. The inclusion/exclusion nexus of the welfare state model is further held by the commission to having been a baseline for migration policy since the 1970s (ibid., p. 12). Again, we see evidence of control over membership as part and parcel of the Norwegian welfare state model.

Social rights are at the core of modern citizenship and the welfare state model that has manifested itself as part of the Nordic model. The Welfare and Migration Commission highlights this (ibid., p. 12), and in the same paragraph where it underscores that social rights are central to realizing equality between members of society it presents a caveat: 'At the same time, the need of the welfare state to control its geographical borders increases as newcomers from outside are accorded more rights'. In citizenship politics, such a quote is a clear example of an exclusionary idea linked to membership and access to rights. I argue that, still considering my previous caveat on the explicitness of citizenship in the commission report, this points in the direction of linking welfare state discourse to membership. A relatively concrete notion of membership politics as an institutional consideration tightly connected to a specific welfare state model comes to the fore. This is even more evident in sections of the report where a clear linkage is made between rights proliferation and the regulation of migration (ibid., pp. 22-23). After all, being granted status as a longterm resident can be seen as the first step toward naturalization and full Norwegian citizenship. In this sense, migration policy serves as an intervening institutional steering mechanism that makes inclusion less likely for more migrants than was previously the case.

The EEA agreement grants EU citizens free movement and access to rights in Norway given certain conditions. There is not much room for manoeuvre regarding the EEA agreement as 'classic' migration policy. This is acknowledged throughout 
the report (ibid., pp. 16, 83). Still, the commission does make some membership considerations linked to the EEA, for instance stating that as the possibilities for regulation of intra-EEA migration are low, more indirect measures connected to tax policy, wages, access to welfare goods, cost of studies etc. are the only options of the government (ibid., p. 16). Nevertheless, it is notable that the commission still makes this link between intra-EEA migration and the possible problems this may pose to the future sustainability of the welfare state.

There have not been major revisions to the Norwegian Citizenship Law in the aftermath of the Welfare and Migration Commission. The main principles of the Citizenship Law are still in place. These principles include citizenship acquisition through ius sanguinis, the prohibition of dual nationality and a residence requirement of seven years. Still, around the time of the work of the commission and in its aftermath there have been some minor revisions. In June 2011, the Norwegian Parliament co-legislated revisions to the so-called Introductory Programme for immigrants and the Citizenship Law, focusing on an increase in mandatory lessons in Norwegian. ${ }^{10}$ This language requirement was introduced both as a measure of integration for new migrants and as an additional requirement for naturalization to Norwegian citizenship. In discursive terms, this is highly interesting. A main argument of this chapter is that the shift in citizenship politics has coincided with a much stronger focus on the issue of membership in what we can call the welfare society. Indeed, in this policy development, the Norwegian Parliament emphasized this new steering logic where access to welfare benefits and ultimately citizenship is premised on an idea of membership as more than rights. That is, membership is contingent on language proficiency and societal participation. The Norwegian Parliament was unanimous in its decision on this matter, which further attests to a hegemonic discourse at work.

Moreover, this policy development was further reinforced in the most recent minor revision to the Citizenship Law. ${ }^{11}$ All parties in the Norwegian Parliament, with the exception of the Socialist Left (SV), voted in favour of the centre-right government's proposal to add a mandatory test on 'civic knowledge' to the naturalization requirements. In addition, a higher level of language proficiency was added to the law. In the debate, ${ }^{12}$ several of the representatives highlighted a direct link between language, integration, rights and citizenship. The welfare dimension was not directly addressed in this policy shift, yet it is clear that adding tougher requirements for would-be citizens increases the gatekeeper function of citizenship related to the welfare state. After decades of virtual silence on citizenship policy in Norway, it has

10 Vedtak til lov om endringer i introduksjonsloven og statsborgerloven, Lovvedtak 60, 2010-2011, 8 June 2011.

11 Vedtak til lov om endringer i statsborgerloven (krav om norskkunnskaper og bestått prøve i samfunnskunnskap), Lovvedtak 23, 2015-2016, 8 December 2015.

12 Stortinget, 2015-2016, meeting, 8 December 2015. 
become strongly politicized and a steering instrument for the state in keeping control of access to the political community in a new age of migration, porous borders and transnational rights.

\subsection{Concluding Remarks: Institutional Change and Democratic Implications}

Citizenship politics and welfare state discourses are related. The two institutions and sets of practices are at the core of individual membership and political community in the modern political order. In this chapter, I have shown how citizenship as an institution and status of membership and rights have become increasingly entangled with the discourse on the welfare state and its sustainability in what can be called the Nordic model by way of Norway as an example. National citizenship is no longer taken for granted as a stable practice of membership within well-defined borders as processes of Europeanization, globalization and migration have marked the period after the end of the Cold War.

The main findings and arguments of this chapter clearly have implications, then, for our understanding of contemporary institutions and their democratic status. While these conjectures are based on a limited, single case study, it is still valuable to discuss such implications. Norway is a 'high achiever' in the international game of successful states. It scores high on most indicators on democratic rule, social equality, trust and human well-being. That the 'Nordic model' is so heavily imbued with changing policy discourses on citizenship and the welfare state is thus clearly interesting.

One main finding of the chapter is that boundary-drawing has taken centre stage. The question of boundaries has engulfed citizenship politics to the extent that it is now the starting point for policy debate rather than a part of the whole or the end point. This is remarkable as the multiculturalist ideas that have long dominated elite debates on citizenship were premised on identity as 'constructed' and boundaries as malleable as well as of lesser importance than in the 'heyday' of the nation-state. What is more, the notion of boundaries is imbued with a discourse on identity or 'belonging' as a prerequisite for access to full membership within the polity. Thus, the idea that identity is something you develop as a consequence of membership and rights has given way to the rather overwhelming narrative that identity is a prerequisite for the 'suitability' of would-be citizens. Moreover, this points to the increased leverage of the idea that the solidarity of the welfare state is necessarily primordial and bounded by the confines of the territorial nation-state in addition to the linkages based on class or profession. Democracy is not only a system of decision-making and (re-) distribution; it is also a system of individual rights. National democracy has been at the pinnacle of modern political order, yet, in the postwar years it has increasingly become interconnected with transnational and supranational political institutions. 
In terms of democracy as a system of rights, it is interesting, then, that access to rights seems to become tightened as the state uses citizenship as an institutional gatekeeper of the political community and the welfare state. This makes the route to full membership through citizenship more cumbersome and less straightforward, even for long-term resident non-nationals. In a normative sense, this can be seen as somewhat problematic. Long-term residency implies a strong connection to the country of residence. Walzer (1983) has indeed argued that although the granting of membership is the sole prerogative of the community that chooses, settled and longterm residents should have 'easy' access to citizenship. The reason for this is that they have participated in the making of common goods of which only full citizenship renders full enjoyment.

While the nation-state clearly is no longer the sole provider of individual rights, the mode of inclusion and exclusion is still strongly attached to it. There is, then, a potential disjuncture between rights, membership and identity in our time. As a result of this, the complexity of citizenship and membership has increased. The shift in citizenship politics from silent policy to steering logic may further trickle down into migration and asylum policies. With the recent handling of the European migration crisis, it is clear that a notion of restricted membership and access to rights has gained considerable political traction - not only in Norway but also in other Northern European countries. Long-standing principles of asylum rights and due process in the processing of asylum applications are under pressure. The idea that the political community is closed and accessible only to insiders who fulfil certain prerequisites and standards is gaining ground. This chapter has only scratched the surface of the citizenship/welfare nexus by analyzing notions of membership. More research is needed in the future to gain a more complete understanding of the linkages between public opinion, political discourses and policy shifts in the 'management' of state borders in Norway, the Nordic countries and Europe as a whole.

\section{References}

Anderson, B. (1987). Imagined Communities. London: Verso.

Cohen, E. (2009). Semi-Citizenship. Cambridge: Cambridge University Press.

Arendt, H. (1968). Men in Dark Times. New York: Harcourt Brace.

Aristotle (1992). The Politics (T.A. Sinclair, Trans.). London: Penguin Books.

Bellamy, R. (2004). Introduction: The making of modern citizenship. In R. Bellamy, D. Castiglione and E. Santoro (Eds.), Lineages of European Citizenship: Rights, Belonging and Participation in Eleven Nation States (1-21). London: Palgrave.

Dobson, L. (2007). Supranational Citizenship. Manchester: Manchester University Press.

Faist, T. (2009). The Transnational Social Question. Social Rights and Citizenship in a Global Context. International Sociology, 24(1), 7-25.

Flora, P. (Ed.) (1987). State, Economy, and Society in Western Europe 1815 - 1975: A Data Handbook in Two Volumes. Frankfurt am Main: Campus. 
Gerstenberg, O. (2001). Denationalization and the Very Idea of Democratic Constitutionalism: the Case of the European Community. Ratio Juris, 14(3), 298-325.

Habermas, J. (1998). The Inclusion of the Other: Studies in Political Theory. Cambridge, MA: MIT Press.

Held, D., McGrew, A., Goldblatt, D., \& Perraton, J. (1999). Global Transformations. Stanford: Stanford University Press.

Hernes, H. (1988). Scandinavian Citizenship. Acta Sociologica, 31(3), 199-215.

Howard, M. M. (2009). The Politics of Citizenship in Europe. Cambridge: Cambridge University Press.

Janoski, T. (2010). The Ironies of Citizenship. Naturalization and Integration in Industrialized Societies. Cambridge: Cambridge University Press.

Kivisto, P., \& Faist, T. (2007). Citizenship. Discourse, Theory, and Transnational Prospects. Oxford: Blackwell.

Kjelstadli, K., Tjelmeland, H., \& Brochmann, G. (2003). Norsk innvandringshistorie, bind 3: I globaliseringens tid, 1940-2000. Oslo: Pax forlag.

Kymlicka, W., \& Norman, W. (1994). Return of the Citizen: a Survey of Recent Work in Citizenship Theory, Ethics, 104(2), 352-381.

Kymlicka, W. (1995). Multicultural Citizenship. Oxford: Oxford University Press.

Maas, W. (2007). Creating European Citizens. Lanham, MD.: Rowman \& Littlefield.

Marshall, T. H. (1992). Citizenship and Social Class. London: Pluto Press.

Miller, D. (1995). On Nationality. Oxford: Clarendon Press.

NOU (2000: 32). Lov om erverv og tap av norsk statsborgerskap. Oslo: Statens forvaltningstjeneste.

NOU (2011: 7). Velferd og migrasjon. Den norske modellens framtid. Oslo: Departementenes servicesenter.

Olsen, E. D. H. (2005). Mellom rettigheter, kultur og cosmopolis. En teoretisk og empirisk analyse av europeisering og statsborgerskap. ARENA Report 7/05, Oslo: ARENA, University of Oslo.

Olsen, E. D. H. (2008). The Origins of European Citizenship in the first Two Decades of European Integration. Journal of European Public Policy, 15(1), 40-56.

Olsen, J. P. (2007). Europe in Search of Political Order. An Institutional Perspective on Unity/Diversity, Citizens/Their Helpers, Democratic Design/Historical Drift and the Co-existence of Orders. Oxford: Oxford University Press.

Schierup, C-U., Hansen, P., \& Castles, S (2006). Migration, Citizenship, and the European Welfare State. Oxford: Oxford University Press.

Schmidt, V. A. (2010). Taking Ideas and Discourse Seriously: Explaining Change through Discursive Institutionalism as the Fourth 'New Institutionalism'. European Political Science Review, 2(1), 1-25.

Sen, A. (Ed.) (1999). Development as Freedom. New York: Anchor Books.

Soysal, Y. (1994). Limits of Citizenship: Migrant and Postnational Membership in Europe. Chicago: University of Chicago Press.

Spiro, P. J. (1997). Dual Nationality and the Meaning of Citizenship. Emory Law Journal, 46(4), 491-565.

Taylor, C. (1985). Human Agency and Language. Philosophical Papers 1. Cambridge: Cambridge University Press.

Tellmann, S. M. (2016). Experts in Public Policymaking: Influential, yet Constrained (Doctoral thesis). Oslo and Akershus University College of Applied Sciences, Oslo, Norway.

Thaa, W. (2001). 'Lean' Citizenship: The Fading Away of the Political in Transnational Democracy. European Journal of International Relations, 7(4), 503-523.

Vink, M. (2005). Limits of European Citizenship. Houndmills: Palgrave.

Walzer, M. (1983). Spheres of Justice. New York: Basic Books.

Weber, M. (1978). Economy and Society: An Outline of Interpretive Sociology (G. Roth \& C. Wittich, Trans. and Eds.). Berkeley, CA: University of California Press (Original work published 1922). 